\title{
Does dogma have a future?
}

\author{
C.J. Wethmar \\ Department of Systematic Theology \\ University of Pretoria \\ PRETORIA \\ E-mail: dogmsend@ccnet.up.ac.za
}

\begin{abstract}
Does dogma have a future?

This article deals with the question whether the negative connotation that the term dogma has developed in its present-day usage poses a threat to the future validity and relevance of doctrine in the church. In an attempt to answer this question an analysis is made of the development of the notion of dogma since its initial appearance in Greek thinking up to its function in the contemporary ecclesiastical context. The conclusion drawn from this analysis is that the negative connotation currently attached to this notion can be ascribed to its reduction either to intellectualism or to legalism. This reduction can be obviated by rediscovering the integrative character of dogma that characterised the praesymbola in the New Testament and is furthermore implied by the Reformed doctrine of the clarity of Holy Scripture.
\end{abstract}

\section{Afrikaanse opsomming}

\section{Het dogma 'n toekoms?}

In hierdie bydrae word aandag geskenk aan die vraag of die negatiewe konnotasie wat tans in die algemene spraakgebruik aan die term dogma geheg word, 'n bedreiging inhou vir die voortgesette geldigheid van die leer in die kerk. In 'n poging om hierdie vraag te beantwoord, word 'n ontleding gemaak van die ontwikkeling van die dogmabegrip vanaf sy Griekse oorspronge tot en met die funksionering daarvan in hedendaagse kerklike verband. Uit hierdie ontleding blyk dat die vermelde negatiewe konnotasie saamhang met 'n reduksie tot onderskeidelik intellektualisme en legalisme wat mettertyd in die dogmabegrip ingetree het. Die kernstelling van hierdie artikel is dat hierdie reduksie vermy kan word indien vasgehou word aan die integrale aard wat die fenomeen van die dogmatiese in sy Nuwe-Testamentiese oorspronge gekenmerk het en wat verder 
bevestig is deur die integrasie van die elemente van kennis, vertroue en gehoorsaamheid in die geloofsbegrip wat met die Reformatoriese leer aangaande die duidelikheid van die Skrif korreleer.

\section{Introduction}

The discipline of dogmatics occupies itself with the dogma of the church (Sauter, 1998:96). The term dogma in the Western world, however, currently has a very negative meaning. It is inter alia associated with attitudes like rigidity, authoritarianism and even irrationality. The question therefore arises whether a term with such a negative meaning can be used to indicate the officially accepted teaching of the church. One, in other words, can ask the question whether dogma has a future (O'Collins, 1975; Dulles, 1973).

On the other hand, one does notice that theologians and church members still continue referring to and taking cognisance of dogmas. And that does not only happen in Roman Catholic theology but in Protestant theology as well. In the light of this fact the additional question can be asked whether the negative meaning attached to the term dogma does justice to the phenomenon it refers to. Are dogmas really as bad as the current usage of this term would have us to believe?

These questions can only be answered if one conducts a careful investigation into the development and present status of the term dogma as well as the phenomenon it refers to.

\section{Dogma as opinion}

The original Greek noun for the concept of dogma was derived from the verb dokei which, in classical Greek, already had the twofold meaning of opinion on the one hand, and decision on the other. During the Hellenistic period each of these two connotations attached to the word dogma developed focused technical meanings (Nolte, 1971:25; Söll, 1971:25).

In the first instance the concept of dogma in the sense of opinion developed the further connotation of philosophical view or doctrine. Inititially it specifically referred to the philosophical doctrine of stoicism but was later used as a term referring to a philosophical theory in general. Gradually the early Christian apologists started using the term dogma in this sense as indicative of Christian doctrine (Nolte, 1971:26). A remarkable peculiarity that can be noted in conjunction with the development that has been referred to is that the Greek word for a theological school or tradition was hairesis, a word from which the word heresy in modern languages is derived. And since a philosophical school 
and the theories or doctrines that it represents are usually identified with each other, one faces the remarkable and ironic fact that in the third and fourth centuries of the Christian era the words dogma and heresy often appeared as synonyms in Greek usage.

A further dimension associated with the idea of dogma as referring to a philosophical theory or tradition that one should take note of, is that of systematic coherence (Elze, 1964:425; Gunton, 1999:21). This is implied by the fact, for example, that when authors like Origen and Eusebius of Caesarea use the term dogma as a singular noun they in fact intend referring to the totality of Christian doctrines that are in a diversity of ways related to one another and impact on one another.

To give one further illustration of the complexity of the notion of dogma one could refer to the fact that by the middle of the fourth century Basil of Caesarea used the term dogma not to indicate the public doctrine of the church but rather its mystic tradition enacted in the sacramental rituals of the church (Elze, 1964:432).

This first aspect of the word dogma that refers to opinion or philosophical theory or even mystic tradition gradually developed such a subjectivistic connotation that it was no longer regarded as suitable to give expression to the normative doctrine of the church. For this reason, since the fifth century, the term dogma was no longer used in church and theological circles. In its place other terms were used to describe the official doctrine of the church. Examples that can be mentioned in this regard are terms like regula fidei, articulus fidei or veritas.

\section{Dogma as decision}

As I have already indicated the Greek term dogma originally had a second meaning, that is: decision. Perhaps one could say that apart from a subjectivistic connotation it also had an objectivistic one. During the Hellenistic period the term dogma with the meaning of decision became the technical term denoting a decision taken by the state or its representative. The implication of this development was that the term dogma acquired a predominantly legal connotation. What is furthermore important to take note of is that in the New Testament the term dogma functions in this way. The term dogma appears six times in the New Testament, and in three instances it refers to an official commandment of the emperor (Luke 2:1; Acts 17:7 and Hebr. 11:23): while in two instances it refers to the regulations of the Jewish law (Eph. 2:15; Col. $2: 14)$ and once to the decisions of the meeting of apostles in Jerusalem (Acts 16:4). This tendency continued and received special emphasis when Christianity became the official state religion in the Constantinian 
era. This situation also implied that the doctrinal decisions of the church were accorded the authority of the laws of the state (Elze, 1964:433). What the theological implications of this development were will be discussed in the following sections of the article.

\section{From Vincentius to Vatican I}

It has already been indicated that since the fifth century of the Christian era the term dogma was no longer used to refer to the normative doctrine of the church. This happened because the stigma of subjectivism became attached to this word. We have on the other hand also seen that at present the term dogma and dogmatics continue to play a role in theological discussions. This raises the question how the term dogma has become reintroduced into the theological tradition. To answer this question one has to refer to a small but famous book by the fifthcentury theologian Vincentius of Lerinum (Kremser, 1959). The main achievement of this book was the clear definition of catholicity that it provided. This definition could also be regarded as giving an accurate description of what a dogma is. The famous formulation that Vincentius (Commonitorium 2/3) used in this regard was the well known phrase id quod ubique, quod semper, quod ab omnibus creditum est. This phrase can be translated as meaning that a valid Christian conviction is one that has been believed everywhere, always and by all. This implies that the criteria according to which a dogma of the church can be identified are those of universality, antiquity and consensus. A conviction that complies with these criteria can be regarded as a deposit of faith that has been entrusted to the church. It was the intention of Vincentius' book to defend this deposit of faith against the innovations of heretics. In this respect he therefore emphasized that one should say old things in new ways but that one is not allowed to say new things nove dicere sed non nova (Vincentius Lerinensis, Commonitorium 22/27).

The book of Vincentius did not receive much attention in the fifth century when it was written. Only during the sixteenth century when the Roman Catholic Church regarded his views as opportune in their defense against what they regarded as the impermissible innovations of the Reformation, did Vincentius' book become popular. This was the case to such an extent that during the sixteenth century alone thirty five editions and twenty two translations of the Communitorium, as this book was called, were published. Through the increased influence of this book as well as through the increased respect for the classical Greek language that developed during the Renaissance period in Europe, the word dogma started to be used more frequently in ecclesiastical and theological contexts again. In theological controversies between Protestantism and Roman Catholicism during the post-Reformation period 
and especially during the eighteenth century, the term dogma gradually acquired the meaning of doctrine that has officially been declared by a church as having been revealed by God. This meaning was formally endorsed by the first Vatican Council of the Roman Catholic Church in 1870 (Kasper, 1965:37). When this notion of dogma is combined with the doctrine of the infallibility of the pope - as happened at the First Vatican Council - the result is a legalistic and authoritarian approach to church doctrine. That this was not merely a theoretical option but was regularly applied in practice can be demonstrated by the way in which the Roman Catholic church dealt with the modernist crisis in the encyclical Pascendi dominici gregis (1907), with the so-called théologie nouvelle in the encyclical Humani generis (1950) and with the postmodernist crisis in documents like Donum veritatis (1989) and Ad tuendam fidem (1998). When these Roman Catholic documents are mentioned it does not imply that an authoritarian and legalistic approach is restricted to this denomination only. It can occur in any church and the basic question that should be asked is whether such a legalistic approach is an adequate and meaningful application of church doctrine.

\section{Prefigurations of dogma}

To answer this question one should keep in mind that doctrine is a mode or expression of the Christian faith, and this faith has its origin in the gospel regarding Jesus Christ (McGrath, 1990:32). In trying to ascertain the nature of Christian doctrine the question could therefore be asked whether dogmatic or doctrinal guidelines are found in Holy Scripture itself. The question is all the more relevant since the famous historian of dogma, Adolf von Harnack, defended the position that the dogmatic expression of the Christian faith had its origin in the influence that Greek culture had on the gospel itself (Meijering, 1985). In responding to Harnack I would suggest that one should not neglect the simple and obvious fact that the transition from a Jewish to a Greek mode of expression is reflected in the Bible itself, while a close study of the New Testament reveals the presence of what has been called prae-symbola or prefigurations of doctrinal expressions.

These praesymbola take on the form of fixed formulas that can be identified by a number of exegetical procedures. Quite often the presence of technical Greek terms like paralambanein, paradidonai, homologein and pisteuein may be indicative of the occurrence of such formulas. In other cases formulations that do not seem to fit well into a specific grammatical construction or even into the relevant context might reveal the presence of such a doctrinal formulation. Attempts to investigate the nature of the praesymbola reflect a consensus of the 
validity of the mentioned criteria in the identification of these prefigurations of doctrinal formulations (Wethmar, 1977:49-65).

A further important result of this research is the insight that these praesymbola functioned in a variety of contexts of which the most important were baptism, the liturgy of the worship service, situations of persecution as well as in situations where heresies had to be opposed. A reference to the latter two will suffice to give an indication of what I have in mind.

In first instance situations of persecution will be mentioned. The early church existed in a context of Roman imperial rule. This was a situation in which total loyalty to the Roman emperor was demanded. This loyalty had to be expressed by the formula kurios kaisar. Christians were unable to agree with this because they had only one final loyalty and that was to Christ. And when they were persecuted as a result of their loyalty, as often happened, they held on to their conviction by merely expressing the confession kurios Jesus: Jesus is Lord and nobody else (Neufeld, 1963:63).

The second instance of a context in which the earliest Christian confessions functioned was that of heresy. The first letter of John provides a clear example in this regard (Wengst, 1976). In the very first verse of this letter John refers to Jesus as the One whom we have seen, whom we have heard and whom we have touched with our hands. Why does John write in this manner? He does so because the people he is writing to are threatened by the heresy of gnosticism. According to this heresy everything related to human embodiment is evil. It was therefore inconceivable to the gnosticists that Jesus could have had a human body and could have died on the cross. In order to oppose the views of the gnosticists John repeatedly uses the fixed doctrinal formulas that we have come to see as the earliest Christian confessions in a specific way. Whenever he uses the fixed expression that Jesus is the Christ, this confession is extended with the phrase "he who came in the flesh" (1 John 4:2 and 3). By means of this extended formulation an established confession is used to combat heresy.

\section{Dogma as integrative concept}

Much has been said about the criteria, contexts and functions of the praesymbola or preliminary doctrinal formulations in the New Testament. But how can their nature and characteristics be described? Research of this material has gradually developed a consensus that with reference to a text like Romans 10:9 the earliest Christian confessions can be divided into two main categories. To understand the distinction between these 
categories one should look carefully at the text stating: "If you confess with your mouth 'Jesus is Lord', and believe in your heart that God raised him from the dead, you will be saved" (Rom. 10:9). On the basis of this distinction between the phrases confess with the mouth and believe with the heart scholars started distinguishing between two categories of confessions. These categories were called homologia and credo, referring to the original Greek words for confess and believe respectively (Conzelmann, 1974:109). The term homologia is indicative not of the content of faith but of faith as a deed or an act. This category of confession or doctrine mainly consists of ascribing a specific title to Jesus. Examples of these titles are those calling Jesus Christ, Lord or Son of God. Regarding this aspect of Christian confession the emphasis is not on the content of Christian faith but rather on confession as an act. This dimension of Christian confession is best illustrated by referring to the first Christian confession described in Matthew 16. In this pericope Jesus asks his disciples who the people say that he is. They responded by mentioning the various theories that people had in this regard. This theoretical approach was obviously not the right mode of speaking about Jesus because it prompted his next question. "But what about you, who do you say I am?" The Christian faith is not merely theoretical talk without any obligation. Faith requires a commitment and a decision. And this is what happens when Peter, on behalf of the disciples, responds to the question of Jesus. Peter answers: "You are the Christ, the Son of God". Peter commits his life to the one who is not merely a prophet but God himself. But one should realise that a commitment like this is not one without obligation. This Peter discovered when Jesus had to appear before the high priest (Matth. 26:70). According to the gospel a servant girl at this occasion asked Peter whether he was a follower of Jesus. Peter denied Jesus by saying that he did not know him. Denial is the exact opposite of confession. Peter discovered that confessing Jesus as Lord and Christ can be very costly. It can cost one one's life.

The first dimension of a Christian confession emphasized by Romans 10:9 therefore is confession as an enactment of Christian faith; as decision and commitment. This implies that a confession is much more than merely having a theory about Jesus or simply knowing something about God. And as such it is more than a mere human act. A real confession of faith is a spiritual event. Therefore the apostle Paul writes in 1 Corinthians 12:3 that no one can say "Jesus is Lord" except by the Holy Spirit. Whenever Jesus is confessed as Lord the Holy Spirit is working, whenever the Holy Spirit works Jesus is confessed as Lord.

The second dimension of a Christian confession that can be identified in the light of Romans 10:9 and that had been indicated above by the term 
credo is that it provides a description of the saving work of Christ as the content of the Christian faith and as the basis of a commitment to Christ.

This distinction between homologia and credo, between a statement of commitment and a statement of content that was made with reference to an interpretation of Romans 10:9, proved to be applicable not only to the preliminary doctrinal material found in the New Testament but also to later doctrinal statements. The Apostle's creed is a good example in this regard. A close study of this creed indicates that it also reflects this combination of a statement of commitment and a statement of content.

The discovery of this basic distinction in the preliminary doctrinal material of the New Testament as well as in subsequent doctrinal statements was an important step in the development of the insight that doctrine or dogma is a complex and integrative concept that combines a number of elements in a greater whole. This view was further developed and refined by the German theologian Edmund Schlink who made an influential analysis of what he called the basic forms of theological statements. In this analysis Schlink emphasizes that in the way in which the Christian faith is articulated in the New Testament five basic forms or structural elements can be distinguished: prayer, doxology, witness, doctrine and confession. The basic thrust of his argument in this regard is that when the Christian faith is articulated in subsequent creeds and doctrines all these basic forms should simultaneously be present. If one or more of these structural elements are either overemphasized or neglected the result is that the content of faith is inadequately formulated (Schlink, 1961:36).

\section{Intellectualism and legalism}

Such an inadequate rendering of the Christian faith is a constant danger for the church. This assumption can easily be proven by a quick glance at the history of the church and has already been suggested by the previously mentioned analysis of the development of the term dogma with its twofold meaning of theory and law. Corresponding to this twofold meaning a twofold reduction in the Christian faith can be traced: an intellectualistic reduction on the one hand, and a legalistic reduction on the other.

The first reduction implying that the doctrinal element overshadows the other dimensions of faith, gradually developed and became clearly visible in the fifth century of the Christian era. This reduction can be illustrated with reference to the introductory terminology used in various creeds. The Apostolic, Nicene and Athanasian creeds still commenced with the words "we believe" and were regularly used in a liturgical 
context. By the middle of the fifth century, however, the Chalcedonian creed was introduced not with the phrase "we believe" but with the words "we teach that one should confess". These words indicate that the emphasis had, at that stage, moved from an integral faith approach to the intellectual element (Schlink, 1961:38). At that stage faith tended to be reduced to a mere theory with the result that the doxological and existential dimensions of faith became neglected - an aspect which of course had severely detrimental effects on ecclesiastical issues.

The second reduction of the comprehensive Christian faith discernible in early church history is related to an overemphasis of the legal element in faith. This development became particularly clear during the Constantinian era when Christianity became a state religion. This situation caused the tenets of faith to become propagated with the authority of the laws of the state. Whenever this happens the nature of the resulting faith is not a comprehensive spiritual and existential event any more but faith reduced to formal obedience (Rossouw, 1973:204). This development during the Constantinian era was further strengthened and deepened by another influential development in pre-Reformation theology: the idea that the Bible was in itself an obscure book that could only be interpreted by church officials (Rossouw, 1963:64). Furthermore it was assumed that salvation could only be received by partaking of the sacraments of the church, and the precondition for this was absolute obedience to the church. In this respect faith was again reduced and restricted to obedience and dogma transformed to a legal obligation.

\section{Conclusion}

A point has now been reached where an attempt can be made to draw a few conclusions from the analysis that has been made. The initial question was whether the term dogma with all the negative associations attached to it is suitable to be indicative of the officially accepted teaching of the church and whether dogma therefore has a future.

In responding to this question one should in the first instance admit that by the nineteenth century the term dogma had indeed developed a severely authoritarian connotation. One should, however, also remember that it was really only since the eighteenth century that this connotation was established.

On the other hand, one should also keep in mind that the term dogma had such a complex history that it is not entirely fair to ascribe an exclusively negative connotation to it. 
Furthermore, the very fact that other terms have often been used for the phenomenon to which the term dogma refers, is an indication that this phenomenon is a more extensive reality as that to which the term dogma normally refers. It is, however, not easy to find a suitable term for this extended reality of dogma as a phenomenon. Many scholars are of the opinion that the term dogma is too burdened by negative associations to be useful in present-day academic and ecclesiastical matters. One should, however, keep in mind that all the alternative terms that could be suggested, for example doctrine, creed, confession, etcetera, all contain disqualifying elements. What is important is to have, whatever term one uses, determined by the insight that dogma is an integrative concept accommodating the full richness of the Christian faith. The insight that the Christian faith cannot be restricted or reduced to either knowledge or law but that it is a comprehensive reality encompassing knowledge, trust and obedience was rediscovered and emphasized by the Calvinist Reformation, and this was done on the basis of the rediscovery of the fact that the Bible is not characterized by obscurity but by clarity. This clarity is not primarily of a semantic but of a religious nature. The Bible asserts its own authority through the work of the Holy Spirit. Dogma is nothing else than the enactment of this beneficial authority in cultural circumstances different from those in which the Bible came into existence. This authority is beneficial because it confronts each one of us with the old, yet ever relevant question of Jesus: "What about you. Wo do you say that I am?" (Matth. 16:15). If the notion of dogma can be enriched by this insight there is no reason why its future should be threatened.

\section{Bibliography}

CONZELMANN, H. 1974. Was glaubte die frühe Christenheit? (In Conzelmann, H. Theologie als Schriftauslegung. München : Kaiser. p.106-119.)

DULLES, A. 1973. The survival of dogma. Garden City, New York : Image Books.

ELZE, M. 1964. Der Begriff des Dogmas in der Alten Kirche. Zeitschrift für Theologie und Kirche, 61:421-438.

GUNTON, C.E. 1999. Dogma, the church and the task of theology. (In Pfitzner, V. \& Regan, H., eds. The task of theology today. Edinburgh : Clark. p. 1-22.)

KASPER, W. 1965. Dogma unter dem Wort Gottes. Mainz : Grünewald.

KREMSER, H. 1959. Die Bedeutung des Vinzenz von Lerin für die RömischKatholische Wertung der Tradition. Hamburg : Universität Hamburg.

McGRATH, A.E. 1990. The genesis of doctrine. Grand Rapids : Eerdmans.

MEIJERING, E.P. 1985. Die Hellenisierung des Christentums im Urteil Adolf von Harnacks. Amsterdam : North Holland.

NEUFELD, V.H. 1963. The earliest Christian confessions. Leiden : Brill.

NOLTE, J. 1971. Dogma in Geschichte. Freiburg : Herder.

O'COLLINS, G. 1975. Has dogma a future? London : Darton, Longman \& Todd.

ROSSOUW, H.W. 1963. Klaarheid en interpretasie. Amsterdam : Jacob van Campen. 
ROSSOUW, H.W. 1973. Doksologie, ortodoksie, ekumene. (In Bakker, J., red. Septuagesimo Anno. Theologische opstellen aangeboden aan Prof. Dr. G.C. Berkouwer. Kampen : Kok. p. 203-212.)

SAUTER, G. 1998. Zugänge zur Dogmatik. Göttingen : Vandenhoeck \& Ruprecht.

SCHLINK, E. 1961. Die Struktur der dogmatischen Aussage als ökumenisches Problem. (In Schlink, E. Der kommende Christus und die kirchlichen Traditionen. Göttingen : Vandenhoeck \& Ruprecht p. 24-79.)

SÖLL, G. 1971. Dogma und Dogmenentwicklung. Freiburg : Herder.

WENGST, K. 1976. Häresie und Orthodoxie im Spiegel des ersten Johannesbriefes. Gütersloh : Gerd Mohn.

WETHMAR, C.J. 1977. Dogma en verstaanshorison. Amsterdam : Rodopi.

\section{Kernbegrippe:}

dogma

doksologiema

gesag

homologie

Key concepts:

authority

dogma

doxology

homology 